\title{
Improved Orientation Strategy for Energy-Efficiency in Photovoltaic Panels
}

\author{
Gamal M. Dousoky ${ }^{\dagger}$, Abou-Hashema M. El-Sayed*, and Masahito Shoyama** \\ $\dagger *$ Faculty of Engineering, Minia University, Alminia, Egypt \\ ${ }^{* *}$ Graduate School of Information Science and Electrical Engineering, Kyushu University, Fukuoka, Japan
}

\begin{abstract}
This paper presents an improved orientation strategy for energy-efficiency in photovoltaic (PV) panels. Conventionally, PV panels are tilted with the site's latitude angle or the difference between the latitude angle and the solar declination angle. A monthly-based orientation strategy has been proposed and analyzed in this study. The proposed strategy implies that the PV panels are tilted with the monthly-based angle that achieves the maximum incident radiation. Furthermore, the impact of using the proposed orientation strategy and three conventional strategies on the produced power and on the PV system design features has been investigated in detail. A Japanese city (Fukuoka) and an Egyptian city (Al-Kharijah) have been considered as locations for the PV power system installation. The results showed that the proposed strategy achieved an increase in the power produced from the PV power systems at the two different sites, and consequently the required solar cells area can be saved. Therefore, the cost of the PV power system components can be reduced including the solar cells area and the land area.
\end{abstract}

Key Words: Energy efficiency, Photovoltaic power systems, Single-axis tracker, Solar radiation, Tilt angle

\section{NOMENCLATURE}

$S \quad$ : Tilt angle of the surface from horizontal, degrees

$\Phi \quad$ : Latitude angle, degrees

$L_{t} \quad$ : Longitude angle, degrees

$\delta \quad: \quad$ Solar declination angle, degrees

$n \quad: \quad$ The order of the day in the year

$\bar{H} \quad$ : Average daily radiation on a horizontal surface, $\mathrm{kWh} / \mathrm{m}^{2}$

$\bar{K}_{T}$ : Fraction of the average daily extraterrestrial radiation

$\bar{H} o$ : Extraterrestrial radiation, $\mathrm{kWh} / \mathrm{m}^{2}$

$\bar{H}_{T}$ : Radiation incident on tilted surface, $\mathrm{kWh} / \mathrm{m}^{2}$

$\bar{R} \quad$ : Ratio of the daily average radiation on a tilted surface to that on a horizontal surface for each month

$\bar{H}_{d}$ : Monthly average daily diffuse radiations, $\mathrm{kWh} / \mathrm{m}^{2}$

$\bar{R}_{b} \quad$ : Ratio of the monthly average beam radiation on the tilted surface to that on the horizontal surface for each month

$\rho$ : Ground reflectance, varies from 0.2 to 0.7 depending upon the type of ground surface [14]

Manuscript received Jun. 19, 2010; revised Feb. 16, 2011

Recommended for publication by Associate Editor Seung-Ho Song.

$\dagger$ Corresponding Author: dousoky@ieee.org

Tel: +20-86-236-2083, Fax: +20-86-234-6674, Minia University

* Faculty of Engineering, Minia University, Egypt

** Graduate School of Information Science and Electrical Engineering, Kyushu University, Japan $\omega_{s}:$ Hour angle, degrees

$\omega_{s}$ : Sunset hour angle for the tilted surfaces, degrees

$E$ : Yearly energy collected by the photovoltaic surfaces, $\mathrm{kWh} / \mathrm{m}^{2}$

$\eta_{c}(t): \quad$ Hourly solar cells efficiency

$T_{c}(t)$ : Hourly solar cell temperature, ${ }^{\circ} \mathrm{C}$

$T_{a}$ : Ambient temperature, ${ }^{\circ} \mathrm{C}$

$H(t)$ : Solar radiation at $(t)$ hour, $\mathrm{kWh} / \mathrm{m}^{2}$

$\eta_{c r}:$ Cell reference efficiency

$T_{c r}:$ Cell reference temperature, ${ }^{\circ} \mathrm{C}$

$\eta_{t r}$ : Transformation stage efficiency, considered as 0.95

$\eta_{p c}$ : Power conditioning unit efficiency, considered as 0.95

$V_{f}$ : Viability factor takes into account the influence of the variation from year to year, considered as 0.95

$F_{S}$ : Factor of safety includes an allowance for the accuracy of the radiation data, for the weather conditions, and for the probable loss in the array output due to its abstraction by dust, considered as 1.1

30.4 : Average number of days per month

$m$ : Month index

$t \quad$ : Hour index

$\zeta:$ : Tilt angle's monthly modification parameter

\section{INTRODUCTION}

Energy is a basic human need for both human development and economic growth. An international priority is to ensure a secure, reliable, affordable, clean and sustained energy supply. 
Most countries, including Japan and Egypt (where the case studies were conducted), are relatively modest in their supply of conventional energy sources (oil and gas). To ensure long term sustainability of the energy supply, it is clear that we need to exploit other sources in addition to oil and gas.

Renewable energy technologies hold a great promise to meet humanity's energy needs [1]. Photovoltaic (PV) system technologies are becoming increasingly important in electric power generation. This is due to the fact that they provide more secure power sources and pollution free electric supplies.

Solar radiation is the source of energy for PV systems. Solar radiation varies over the earth's surface due to weather conditions and location. For each location, an optimum orientation of the PV cells is desired to obtain the maximum possible incident radiation over the surface of the cells [2]. Great efforts have been made in reducing the required PV cells through the development of solar tracking systems [2]-[11].

Conventionally, PV panels are tilted with a monthly angle $(S=0, S=\Phi$, or $S=\Phi-\delta$ ). In this paper, a monthly-based orientation strategy has been proposed and analyzed. Furthermore, the impact of using the proposed strategy and three other conventional strategies, for PV panels' orientation, on the produced power and photovoltaic system design features has been investigated in detail.

This paper is organized in the following manner. An investigation of different orientation strategies for optimum solar energy harvesting is addressed in section II. Section III presents the impact of the proposed orientation strategy on the estimated solar cells area. Finally, conclusions are presented in section IV.

\section{Investigation of the Best Tilt Angle for OPtIMUM SOlar ENERgy HARVESTING}

\section{A. Investigation Methodology}

The energy generated from solar cells is proportional to the amount of incident light. It reaches its maximum value when the solar cells are perpendicular to the sun's rays [11]. The solar radiation on an inclined surface is a function of the sun's ray $\left(I_{N}\right)$, and some related angles, as described in Fig. 1 [12].

The incident solar energy over tilted surfaces is estimated as in the following steps:

1) Basic Idea: Conventional orientation strategies suggest tilting the PV panels with a monthly-based angle $(S=0, S=\Phi$, or $S=\Phi-\delta$ ), where $\delta$ can be calculated using the following equation [13]:

$$
\delta=23.45^{\circ} \sin [360(284+n) / 365]
$$

This paper proposes an improved strategy for better solar energy harvesting. In this strategy, the tilt angle has been calculated for each month to achieve the maximum incident solar energy over the PV panels for the site under study. Then, these angles have been formulated in an empirical formula for easy and efficient application of the proposed strategy at different sites.

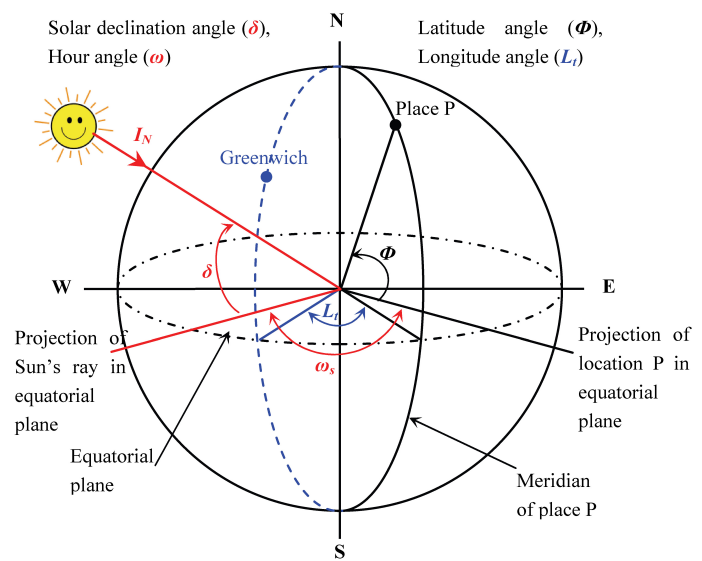

(a) Sun's ray falling on the earth.

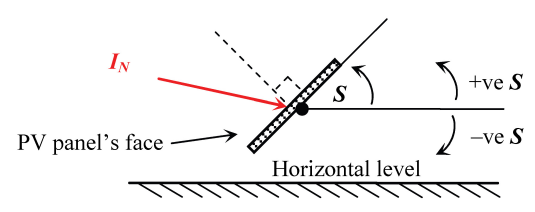

(b) Tilted PV panel (oriented toward the Equator).

Fig. 1. Solar radiation tracking concepts.

2) Calculation of the radiation at different tilt angles: The average daily radiation on a horizontal surface $(\bar{H})$, for each month can be expressed by defining $\bar{K}_{T}$, a fraction of the average daily extraterrestrial radiation $(\bar{H} o)$, as [13]:

$$
\bar{K}_{T}=\bar{H} / \bar{H}_{o}
$$

Then, the average daily radiation on a tilted surface $\bar{H}_{T}$ can be expressed as [13], [14]:

$$
\bar{H}_{T}=\bar{R} \times \bar{H}
$$

where:

$$
\begin{aligned}
& \bar{R}=\left(1-\frac{\bar{H}_{d}}{\bar{H}}\right) \times \bar{R}_{b}+\left(\frac{\bar{H}_{d}}{\bar{H}}\right)(1+\cos S) / 2+\rho(1-\cos S) / 2 \\
& \frac{\bar{H}_{d}}{\bar{H}}=1.39-4.027 \times \bar{K}_{T}+5.531 \times\left(\bar{K}_{T}\right)^{2}-3.108 \times\left(\bar{K}_{T}\right)^{3}
\end{aligned}
$$

$\bar{R}_{b}=$

$$
\begin{gathered}
\frac{\cos (\Phi-S) \times \cos \delta \times \sin \omega_{s}^{\prime}+(\pi / 180) \times \omega_{s}^{\prime} \times \sin (\Phi-S) \times \sin \delta}{\cos \Phi \times \cos \delta \times \sin \omega_{s}+(\pi / 180) \times \omega_{s} \times \sin \Phi \times \sin \delta} \\
\omega_{s}=\cos ^{-1}(-\tan \Phi * \tan \delta)
\end{gathered}
$$

where:

$$
\omega_{s}^{\prime}=\min \left[\omega_{s}, \cos ^{-1}(-\tan (\Phi-S) \tan \delta]\right.
$$

$\bar{H}_{T}$ has been calculated at different tilt angles. $S$ has been swept to identify the value that achieves the maximum collected $\bar{H}_{T}$ every month. The sweeping of $S$ starts from $-90^{\circ}$ up to $90^{\circ}$-including $S=0, S=\Phi$, and $S=\Phi-\delta$. Fig. 2 shows a flowchart for achieving the above addressed methodology. 


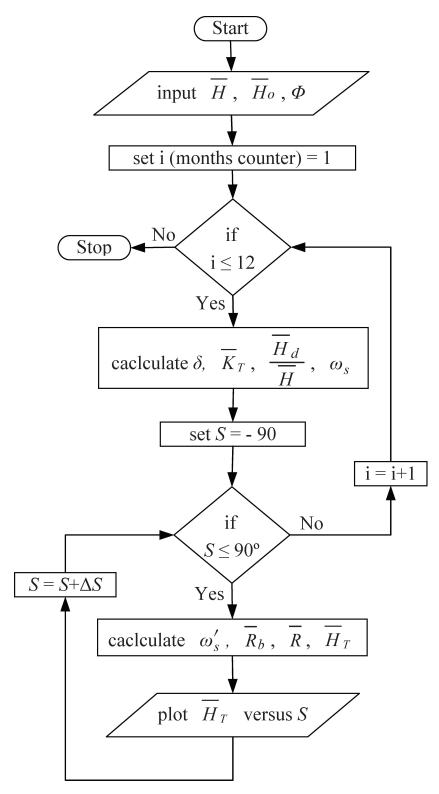

Fig. 2. Flowchart for calculating the radiation at different tilt angles ( $S$ is swept from -90 up to $90^{\circ}$ ).

The yearly energy has been calculated in studied cases as follows:

$$
E=\left(\sum_{m=1}^{12} \bar{H}_{T}\right) \times 30.4
$$

Comparative investigations of the results have been achieved and addressed in the following sections.

\section{B. Application and Results}

The methodology explained in the above section has been programmed in MATLAB and has been applied to the selected Egyptian and Japanese sites: the Al-Kharijah site (latitude angle $25.45^{\circ} \mathrm{N}$, located in the southwest of Egypt) and the Fukuoka site (latitude angle $33.57^{\circ} \mathrm{N}$, located in southwest of Japan). These two sites have different climate conditions (both solar radiation and ambient temperature); which makes them suitable, as sites for study, to evaluate the robustness of the proposed strategy.

\section{1) Required Data:}

- The hourly solar radiation on a horizontal surface, at the selected sites, has been collected over the last five years by the Egyptian Meteorological Authority, [15] and the Japanese Meteorological Authority [16]. Then the average values of these data are calculated. Samples of these data are drawn in Fig. 3 and Fig. 4.

- The ambient temperature for the selected sites.

- The recommended average day for each month [13], illustrated in Table I.

- Using the monthly average daily extraterrestrial radiation at different latitudes [13], and by the interpolation method, the monthly average daily extraterrestrial radiation for the Al-Kharijah site and the Fukuoka site has been calculated and illustrated in Table II.

2) Results and Discussion: The radiation at different tilt angles has been calculated according to the methodology described above as shown in the flowchart presented in Fig. 2.

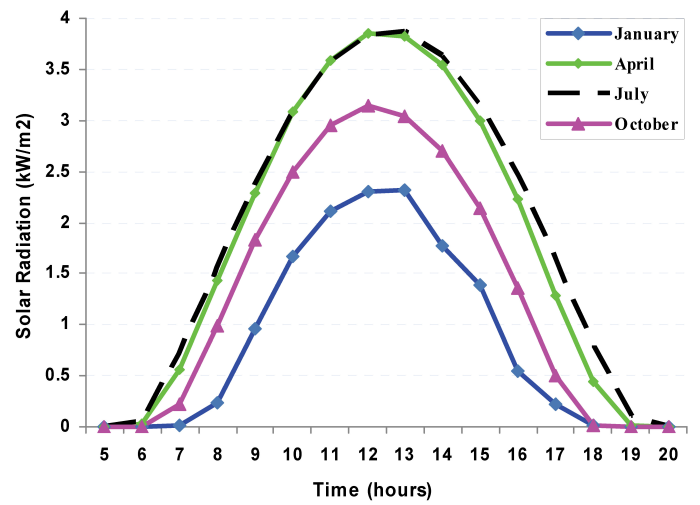

Fig. 3. Sample of the solar radiation on horizontal surfaces at Al-Kharijah site.

The change of $\bar{H}_{T}$ versus the variation of $S$ is plotted for every month at the sites under study (A sample is shown in Fig. 5 and Fig. 6). Moreover, the values of the $S$ that achieves the maximum collected $\bar{H}_{T}$ have been identified (circled in Fig. 5 and Fig. 6; • points).

It can be observed that:

1) Although horizontal orientation of PV panels (at $S=0$ ) achieves good performance in some months (see July in Fig. 5 and Fig. 6); which is close to the calculated maximum (circled point on the curve), it is far away from the calculated maximum in most of the other months.

2) Although the conventional orientation strategy at $S=\Phi$ achieves good performance in some months (see October in Fig. 5 and Fig. 6); which is close to the calculated maximum (circled point on the curve), it is far away from the calculated maximum in most of the other months.

3) The orientation strategy at $S=\Phi-\delta$ achieves better performance than other conventional strategies in most months (see the squared points ( $\mathbf{\square}$ ) in Fig. 5 and Fig. 6, they are always close to the calculated maximum points $(\bullet))$. However, this strategy still needs improvement. Such improvement targets moving the operating states from the current $\boldsymbol{\square}$ points to the $\bullet$ points.

The above discussion leads to the proposed orientation strategy; i.e. the tilt angles that achieve the calculated maximum collected $\bar{H}_{T}$ have been formulated as follows:

$$
S=\Phi-\zeta \delta
$$

where:

$$
\xi=\cos ^{-1}\left(-\delta^{2}\right)
$$

The proposed new formula attains values very close to the target: - points (see Fig. 7 and Fig. 8). It has proven its applicability to different sites with different solar radiations and temperatures.

To estimate the effect of the proposed strategy on the collected solar energy of the tilted surfaces, the yearly incident energy on a unit area has been calculated at both of the sites under study with different orientation strategies $(S=0, S=\Phi$, $S=\Phi-\delta, S=\Phi-\zeta \delta$ ). Then the results have been compared. Table III, and Fig. 9 illustrate the solar radiation, and the 
TABLE I

RECOMMENDED AVERAGE DAY FOR EACH MONTH (NORTH OF THE EQUATOR)

\begin{tabular}{|l|l|l|l|l|l|l|l|l|l|l|l|l|}
\hline Month & Jan. & Feb. & Mar. & Apr. & May. & June & July & Aug. & Sept. & Oct. & Nov. & Dec. \\
\hline Date & 17 & 16 & 16 & 15 & 15 & 11 & 17 & 16 & 15 & 15 & 14 & 10 \\
\hline Day of year & 17 & 47 & 75 & 105 & 135 & 162 & 198 & 228 & 258 & 288 & 318 & 344 \\
\hline
\end{tabular}

TABLE II

MONTHLY AVERAGE DAILY EXTRATERRESTRIAL RADIATION (KWH/M²)

\begin{tabular}{|c|c|c|c|c|c|c|c|c|c|c|c|c|c|}
\hline & Site & Jan. & Feb. & Mar. & Apr. & May. & June & July & Aug. & Sept. & Oct. & Nov. & Dec. \\
\hline $\bar{H} o$ & Al-Kharijah & 6.56 & 7.75 & 9.08 & 10.28 & 10.91 & 11.12 & 11.01 & 10.49 & 9.48 & 8.12 & 6.85 & 6.23 \\
\hline & Fukuoka & 5.25 & 6.61 & 8.26 & 9.80 & 11 & 11.37 & 11.17 & 10.33 & 9.55 & 7.08 & 5.588 & 4.88 \\
\hline
\end{tabular}

TABLE III

Monthly aVerage daily radiation, and yearly energy $\left(\mathrm{KWH} / \mathrm{M}^{2}\right)$ at $S=0, S=\Phi, S=\Phi-\delta$, and $S=\Phi-\zeta \delta$, AT Al-Kharijah Site

\begin{tabular}{|l|l|l|l|l|}
\hline \multirow{2}{*}{ Month } & \multicolumn{3}{|c|}{ Conventional Strategies } & Proposed Strategy \\
\cline { 2 - 5 } & $\bar{H}_{T}$ at $S=0$ & $\bar{H}_{T}$ at $S=\Phi$ & $\bar{H}_{T}$ at $S=\Phi-\delta$ & $\bar{H}_{T}$ at $S=\Phi-\zeta \delta$ \\
\hline Jan. & 3.7682 & 5.0955 & 5.7033 & 5.8268 \\
\hline Feb. & 5.5397 & 7.0093 & 7.3690 & 7.4469 \\
\hline Mar. & 6.2795 & 6.9971 & 7.0112 & 7.0149 \\
\hline Apr. & 8.1002 & 8.0364 & 8.2054 & 8.2250 \\
\hline May. & 8.4331 & 7.5789 & 8.3156 & 8.4741 \\
\hline June & 8.4355 & 7.2593 & 8.3678 & 8.6661 \\
\hline July & 8.5483 & 7.4877 & 8.4443 & 8.6779 \\
\hline Aug. & 7.6908 & 7.3146 & 7.6477 & 7.7032 \\
\hline Sept. & 6.8569 & 7.3059 & 7.3107 & 7.3097 \\
\hline Oct. & 5.9477 & 7.2485 & 7.4598 & 7.5075 \\
\hline Nov. & 4.8445 & 6.6333 & 7.3771 & 7.5512 \\
\hline Dec. & 4.2632 & 6.1712 & 7.2197 & 7.4962 \\
\hline Yearly Energy $(E)$ & 2392.7159 & 2557.7874 & 2749.1239 & 2793.7 \\
\hline
\end{tabular}

TABLE IV

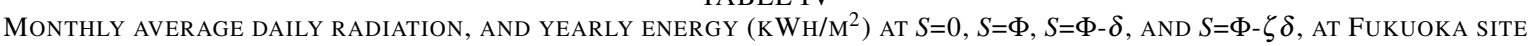

\begin{tabular}{|l|l|l|l|l|}
\hline \multirow{2}{*}{ Month } & \multicolumn{3}{|c|}{ Conventional Strategies } & Proposed Strategy \\
\cline { 2 - 5 } & & & & \\
& & & \\
& at $S=0$ & $\bar{H}_{T}$ at $S=\Phi$ & $\bar{H}_{T}$ at $S=\Phi-\delta$ & $\bar{H}_{T}$ at $S=\Phi-\zeta \delta$ \\
\hline Jan. & 2.0561 & 2.9885 & 3.2622 & 3.2882 \\
\hline Feb. & 2.3589 & 2.9461 & 3.0067 & 2.9939 \\
\hline Mar. & 3.9256 & 4.4979 & 4.4983 & 4.4960 \\
\hline Apr. & 4.8494 & 4.8659 & 4.9752 & 4.9982 \\
\hline May. & 5.6547 & 5.1445 & 5.5690 & 5.6559 \\
\hline June & 3.8144 & 3.3972 & 3.7507 & 3.8238 \\
\hline July & 4.5744 & 4.0964 & 4.4931 & 4.5774 \\
\hline Aug. & 5.3206 & 5.1185 & 5.3406 & 5.3837 \\
\hline Sept. & 3.6522 & 3.8782 & 3.8894 & 3.8942 \\
\hline Oct. & 4.0433 & 5.2674 & 5.3830 & 5.3978 \\
\hline Nov. & 2.8283 & 4.2351 & 4.6171 & 4.6769 \\
\hline Dec. & 2.6500 & 4.4188 & 5.0952 & 5.2454 \\
\hline Yearly Energy $(E)$ & 1390.1 & 1546.0 & 1638.0 & 1654.7 \\
\hline
\end{tabular}

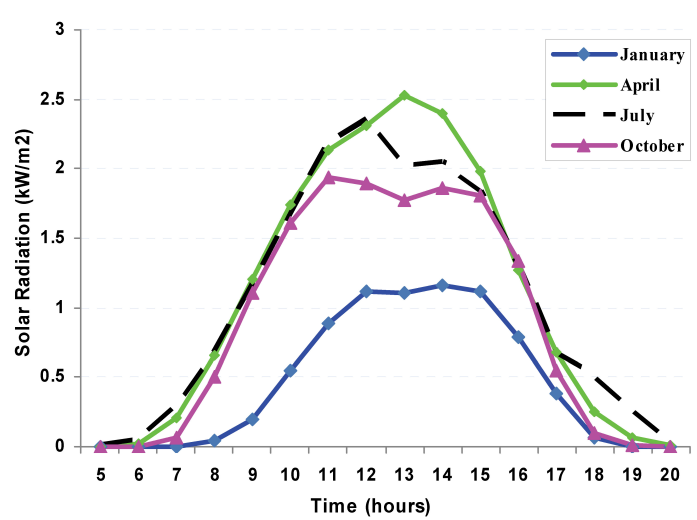

Fig. 4. Sample of the solar radiation on horizontal surfaces at Fukuoka site.

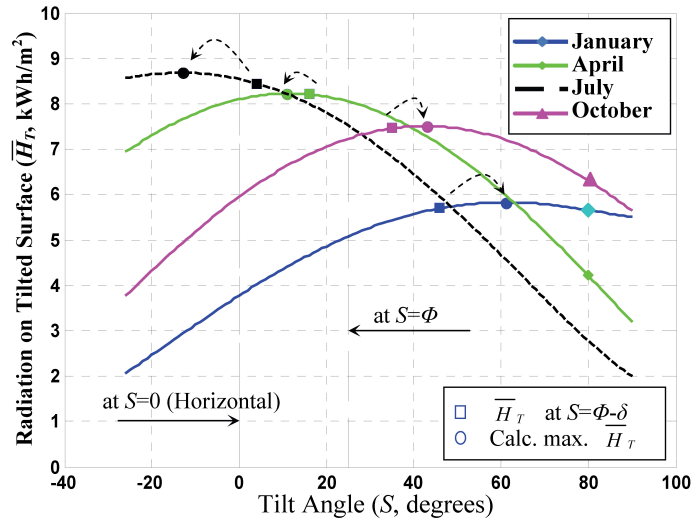

Fig. 5. Sweeping of the tilt angle to identify the value that achieves the maximum collected $\bar{H}_{T}$ every month at Al-Kharijah site. 


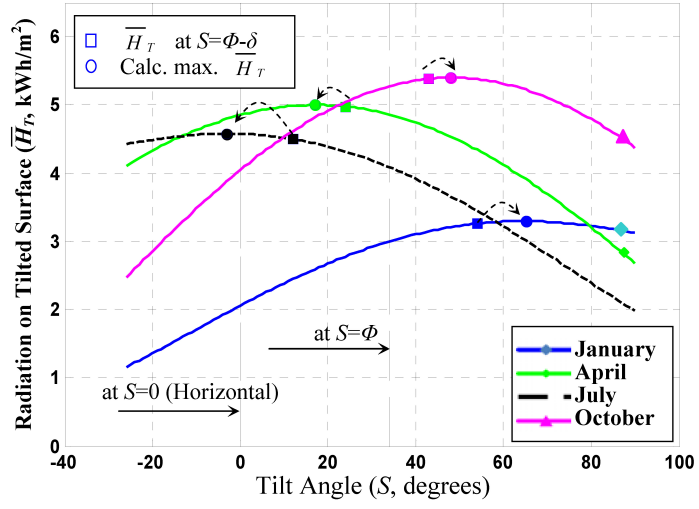

Fig. 6. Sweeping of the tilt angle to identify the value that achieves the maximum collected $\bar{H}_{T}$ every month at Fukuoka site.

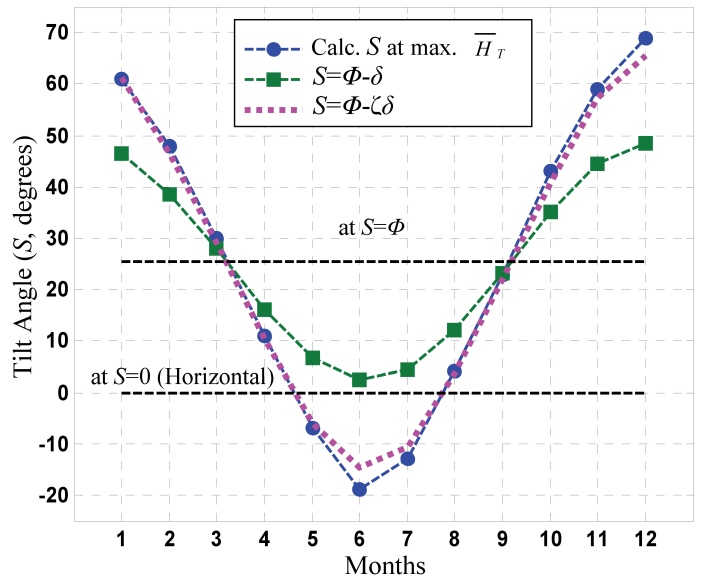

Fig. 7. Curve fitting for the calculated tilt angles that achieve the maximum collected $\bar{H}_{T}$ at Al-Kharijah site.

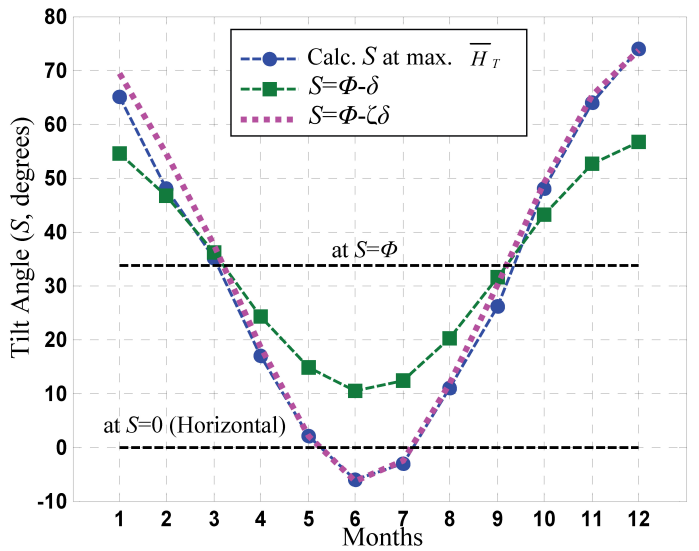

Fig. 8. Curve fitting for the calculated tilt angles that achieve the maximum collected $\bar{H}_{T}$ at Fukuoka site.

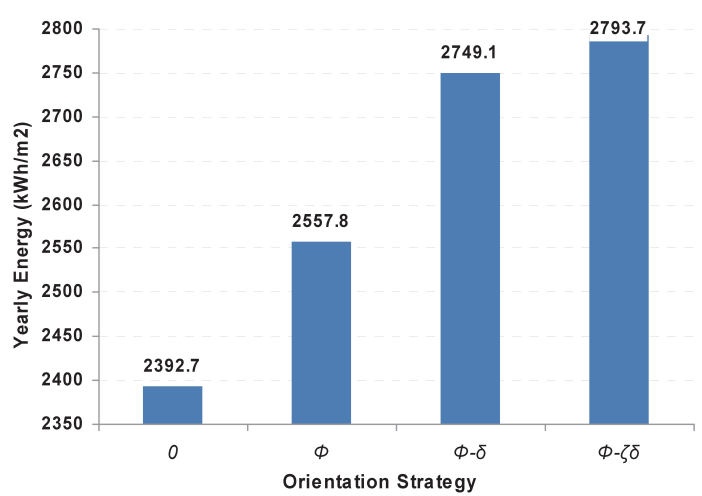

Fig. 9. Effect of the orientation strategy on the yearly-collected solar energy at Al-Kharijah site.

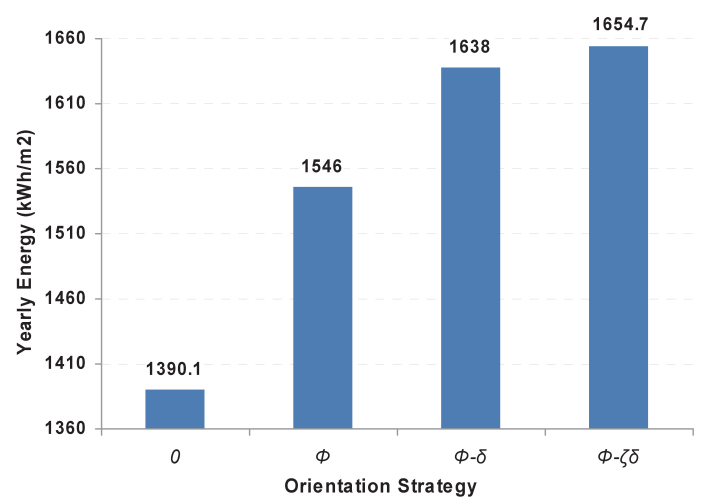

Fig. 10. Effect of the orientation strategy on the yearly-collected solar energy at Fukuoka site.

yearly-collected solar energy, respectively, when the surfaces are tilted at $S=0, S=\Phi, S=\Phi-\delta$, and $S=\Phi-\zeta \delta$ for the Al-Kharijah site. In addition, Table IV and Fig. 10 illustrate the results for the Fukuoka site.

To evaluate the impact of the proposed strategy on PV power system design, an actual case has been investigated and addressed in the following section.

\section{IMPACT OF THE Proposed STRATEGy ON THE REQuired Solar CElls AREa}

The proposed orientation strategy has been applied to the estimation of the required solar cells area for supplying a certain load as follows:

\section{A. Load Specifications}

The forecasted growth in the load demand for the next five years (year 2010 to year 2015) has been estimated for a typical Egyptian city (shown in Fig. 11). The PV power system is designed to supply the energy demand for such load.

\section{B. PV Module Specifications}

The characteristics of the selected PV panels are shown in Table V, [17].

\section{Estimation Methodology for the Required Solar Cells Area}

In order to supply the energy demand, the required solar cells area can be determined as follows: 


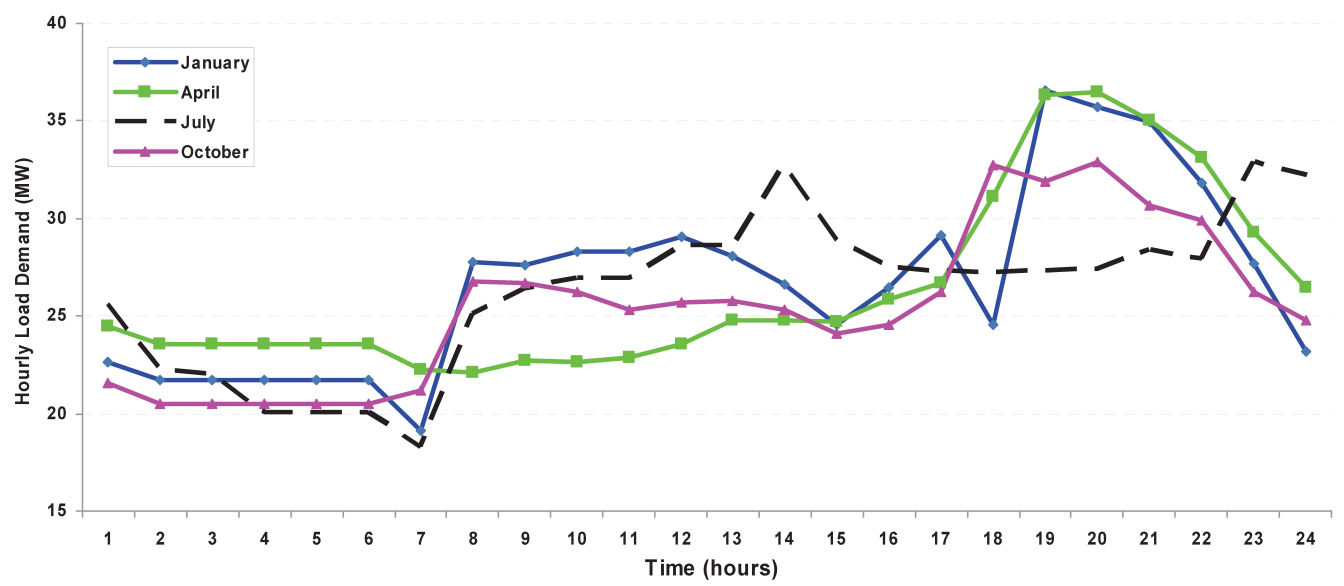

Fig. 11. A sample of the forecasted load demand.

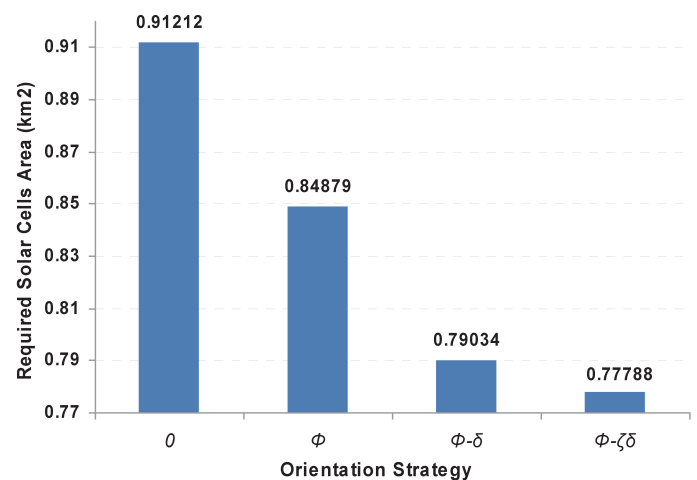

Fig. 12. Effect of the orientation strategy on the required solar cells area at Al-Kharijah site.

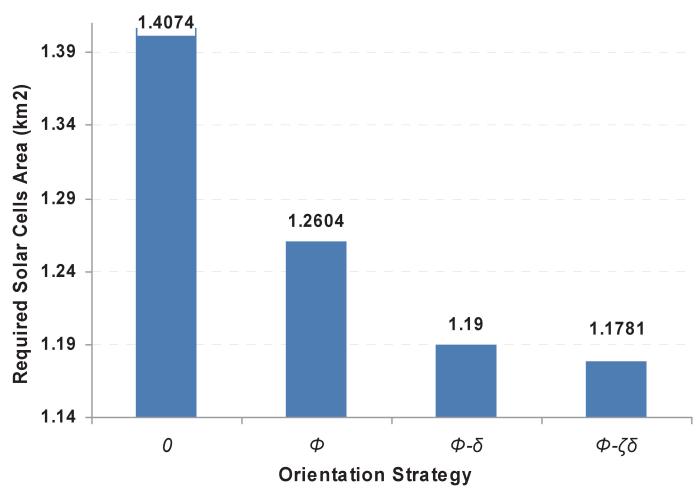

Fig. 13. Effect of the orientation strategy on the required solar cells area at Fukuoka site.

The hourly solar cells efficiency $\left(\eta_{c}(t)\right)$ can be estimated as follows:

$$
\begin{gathered}
T_{c}(t)=T_{a}+0.3 * H(t) \\
\eta_{c}(t)=\eta_{c r}\left[1-0.0062\left(T_{c}(t)-T_{c r}\right)\right]
\end{gathered}
$$

The power produced from $1 \mathrm{~m}^{2}$ of solar cells (PVU), $\mathrm{kW}$ is:

$$
\mathrm{PVU}=1 * H(t) * \eta_{c}(t) * \eta_{T r} * \eta_{P c} * V f / F s
$$

The energy produced from $1 \mathrm{~m}^{2}$ of solar cells (YEVU), $\mathrm{kWh}$ in one year is:

$$
\mathrm{YEVU}=30.4 \times \sum_{m=1}^{12} \sum_{t=5}^{20} \mathrm{PVU}(t, m)
$$

TABLE V

CHARACTERISTICS OF THE SELECTED PV PANELS (TYPE M-55), [17]

\begin{tabular}{|l|l|}
\hline Item & Value \\
\hline Size $(\mathrm{m})$ & $0.33 * 1.219$ \\
\hline Area $\left(\mathrm{m}^{2}\right)$ & 0.40227 \\
\hline $\begin{array}{l}\text { Cell normal operating tempera- } \\
\text { ture }\left({ }^{\circ} \mathrm{c}\right)\end{array}$ & 42 \\
\hline Cell efficiency $(\%)$ & 13.9 \\
\hline Module efficiency (\%) & 13.175 \\
\hline Open circuit voltage (Vdc) & 21.7 \\
\hline Short circuit current $(\mathrm{A})$ & 3.4 \\
\hline Voltage at maximum power $(\mathrm{Vdc})$ & 17.4 \\
\hline Current at maximum power $(\mathrm{A})$ & 3.05 \\
\hline Maximum power $(\mathrm{W})$ & 53 \\
\hline
\end{tabular}

Yearly energy demand for the year (YED), kWh it:

$$
\mathrm{YED}=30.4 \times \sum_{m=1}^{12} \sum_{t=1}^{24} \mathrm{PL}(t, m)
$$

where PL is the hourly load demand for power in $\mathrm{kW}$.

It is clear that, the required solar cells area (SCA) is equal to the YED divided by the YEVU as follows:

$$
\mathrm{SCA}=\mathrm{YED} / \mathrm{YEVU}
$$

\section{Results}

Fig. 12 and Fig. 13 show the estimated solar cells area required for supplying the load demand for the two sites under study with different orientation strategies. From these figures it can be seen that the use of the proposed strategy achieved the smallest solar cells area for the two sites under study.

\section{Conclusions}

Conventionally, PV panels are tilted with a monthly angle $(S=0, S=\Phi$, or $S=\Phi-\delta)$. In this paper, an improved monthly-based orientation strategy has been proposed and analyzed. Furthermore, the impact of using the proposed strategy and three other conventional strategies on the produced power and the PV system design features has been investigated in detail. It can be concluded that:

1) It is not recommended that PV modules be tilted by the angles $(S=\Phi$ or $S=0)$. These cases never achieve the 
best tilted solar radiation, when compared with the other cases: $(S=\Phi-\delta$ and/or $S=\Phi-\zeta \delta)$.

2) The maximum energy harvesting is achieved when the PV panels are tilted with the proposed monthly tilt angle $(S=\Phi-\zeta \delta)$ during all of the months. An imperial formula for the modification parameter $(\zeta)$ has been suggested as $\xi=\cos ^{-1}\left(-\delta^{2}\right)$.

3) The proposed strategy attained an efficient performance when applied to different sites with different solar radiations and temperatures. Thus, it proved its global applicability.

4) Using the proposed methodology $(S=\Phi-\zeta \delta)$ achieved a $12460 \mathrm{~m}^{2}$ saving in the required solar cells area for the Al-Kharijah site; i.e., a 1.6\% decrease in the required solar cells, when compared with the conventional case $(S=\Phi-\delta)$. On the other hand, it achieved a $11900 \mathrm{~m}^{2}$ saving in the required solar cells area for the Fukuoka site; i.e., a $1 \%$ decrease in the required solar cells, when compared with the conventional case $(S=\Phi-\delta)$. Therefore, the cost of the PV power system components can be reduced including the solar cells area and the land area.

\section{REFERENCES}

[1] G. Dousoky, On Intelligent Power Electronic Interface for Renewable Energy Systems: Design, Cost, Reliability Investigations, VDM Verlag Publishing House Ltd., chap. 2-3, Feb. 2010.

[2] L. Mateu, and F. Moll, "Review of energy harvesting techniques and applications for microelectronics," in Proc. SPIE Conference, Vol. 5837, pp. 359-373, 2005.

[3] P. Roth, A. Georgiev, and H. Boudinov, "Design and construction of a system for sun-tracking," Renewable Energy, Vol. 29, No. 3, pp. 393402, Mar. 2004

[4] P. Roth, A. Georgiev, and H. Boudinov, "Cheap two axis sun follow device," Energy Conversion and Management, Vol. 46, No. 7-8, pp. 1179-119, May 2005.

[5] M. Egido and E. Lorenzo, "The sizing of stand-alone PV systems: A review and a proposed new method," Solar Energy Materials and Solar Cells, Vol. 26, No. 1-2, pp. 51-69, Mar. 1992.

[6] M. K. C. Marwali, S. M. Shahidehpour, and M. Daneshdoost, "Probabilistic production costing for photovoltaic-utility systems with battery storage," IEEE Transactions on Energy Conversion, Vol. 12, No. 2, pp. 175-180, Jun. 1997.

[7] M. Benghanem, "An optimal sizing method for stand-alone photovoltaic system for algeria," in Proc. the World Renewable Energy Congress VII, 2002.

[8] W. D. Kellogg, M. H. Nehrir, G. Venkataramanan, and V. Gerez, "Generation unit sizing and cost analysis for stand-alone wind, photovoltaic, and hybrid Wind/PV Systems," IEEE Trans. Energy Convers., Vol. 13, No. 1, pp. 70-75, Mar. 1998.

[9] D. B. Nelson, M. H. Nehrir, and C. Wang, "Unit sizing and cost analysis of stand-alone hybrid wind/PV/fuel cell power generation systems," Renewable Energy, Vol. 31, No. 10, pp. 1641-1656, Jul. 2006.
[10] D. B. Nelson, M. H. Nehrir, and V. Gerez, "Economic evaluation of grid-connected fuel cell systems," IEEE Trans. Energy Convers., Vol. 20, No. 2, pp. 452-458, Jun. 2005.

[11] J. Choi, J. Ko, and D. Chung, "Development of a novel tracking system for photovoltaic efficiency in low level radiation," Journal of Power Electronics, Vol. 10, No. 4, pp.405-411, Jul. 2010.

[12] G. N. Tiwari and S. Dubey, Fundamentals of Photovoltaic Modules and Their Applications, RSC Publishing, 2010.

[13] S. A. Klein, "Calculation of monthly average insolation on tilted surfaces," Solar Energy, Vol. 19, No. 4, pp. 325-329, 1977.

[14] B. Y. H. Liu and R. C. Jordan, "Daily insolation on surfaces tilted toward the equator," Journal of ASHRAE, Vol. 3, No. 10, pp. 53-59, Oct. 1961.

[15] Egyptian Meteorological Authority (EMA).

[16] Japanese Meteorological Authority (JMA)- http://www.jma.go.jp, dateYear2009Day25Month9Sept. 25 ${ }^{\text {th }}, 2009$.

[17] "M-55 Photovoltaic Modules," EGYCEL, Photovoltaic Modules in Cooperation with Siemens Solar GmbH.

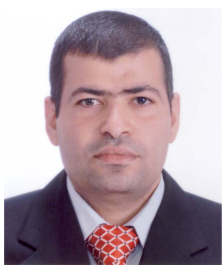

Gamal M. Dousoky received his B.Sc. and M.Sc. from Minia University, Egypt, in 2000 and 2004, respectively, and his Ph.D. from Kyushu University, Japan, in 2010 , all in Electrical Engineering. Since 2000, he has been associated with the Department of Electrical Engineering, Faculty of Engineering at Minia University, as a Teaching Assistant, a Lecturer Assistant, and since 2011, as an Assistant Professor. His research interests include power electronics, especially in renewable energy applications, switching power supplies, EMC/EMI, artificial intelligence, and digital control. He is a member of IEICE, IEEE, and ETRI. Dr. Gamal received the 2009 Excellent Student Award of the IEEE Fukuoka Section.

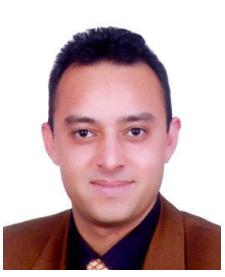

Abou-Hashema M. El-Sayed received his B.Sc., and M.Sc. in Electrical Engineering from Minia University, Minia, Egypt, in 1994 and 1998, respectively. He was a $\mathrm{Ph} . \mathrm{D}$. student in the Institute of Electrical Power Systems and Protection, Faculty of Electrical Engineering, Dresden University of Technology, Dresden, Germany from 2000 to 2002 . He received his Ph.D in Electrical Power from the Faculty of Engineering, Minia University, Egypt in 2002, according to a channel system program, which means a Scientific Co-operation between the Dresden University of Technology, Germany and Minia University, Egypt. Since 1994, he has been with the Department of Electrical Engineering, Faculty of Engineering, Minia University, as a Teaching Assistant, a Lecturer Assistant, and since 2002, as an Assistant Professor. He was a Visiting Researcher at Kyushu University, Japan, from 2008 to 2009 . His research interests include protection systems, renewable energy, and power systems.

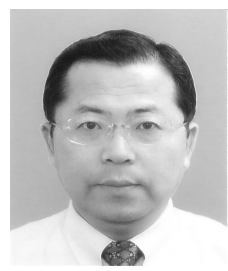

Masahito Shoyama received his B.S. in Electrical Engineering and his Ph.D. from Kyushu University, Fukuoka, Japan, in 1981 and 1986, respectively. He joined the Department of Electronics, Kyushu University as a Research Associate in 1986, and he has been a Professor since 2010. Since 1996, he has been with the Department of Electrical and Electronic Systems Engineering, Graduate School of Information Science and Electrical Engineering, Kyushu University. He has been active in the fields of power electronics, especially in high-frequency switching power supplies, power factor correctors, piezoelectric power converters, and electromagnetic compatibility (EMC). Prof. Shoyama is a member of IEEE, IEICE, IEEJ and SICE. 